\title{
The Influence of Harvesting Time and Curing Techniques on Storability of Onion Bulbs
}

\author{
Dessie Getahun \\ Ethiopian Institute of Agricultural Research Fogera Research and Training Center Woreta, \\ Ethiopia
}

*Corresponding Author: Dessie Getahun, Ethiopian Institute of Agricultural Research Fogera Research and Training Center Woreta, Ethiopia

\begin{abstract}
Onion bulbs in South Gondar zone of northwestern Ethiopia are produced in large quantities during the dry season using irrigation. High storage losses usually compel producers to sell their produce immediately after harvest bringing about a market glut during a season, while price climbs up at another time when there is shortage of supply. The use of appropriate pre-and post-harvest handling practices including harvesting time and curing techniques helps to improve shelf life of onion bulbs without significant deterioration thereby helping to stabilize market price. Furthermore, bulbs for seed purpose could be stored long till the next growing season. This study was therefore initiated to determine appropriate harvesting time and curing techniques (duration and techniques of foliage drying) for good storability of onion bulbs.

Combinations of treatments of different harvesting stages, foliage drying periods and drying methods were evaluated for bulb keeping quality. Immediately after foliage removal retaining only one cm long neck with the bulb, healthy and non bruised bulbs were kept on wire-mesh and wooden made shelves in a DLS and evaluated weekly for rotting, sprouting and physiological weight loss. Mean result on onion bulb storability revealed that almost all interactions with the exception of harvesting stage and year were insignificant $(P<0.05)$. The effect of drying techniques (method) on shelf life of onion bulbs was also found insignificant. On the other hand significant difference on onion bulb storability was recorded from different stages of harvesting and foliage drying periods. In general, harvesting at 25 percent foliage fall over, and drying and curing harvested onion bulbs with foliages for two weeks on wire-meshed and wooden shelves in a DLS at ambient temperature and relative humidity (or in a partially shaded condition) was found appropriate for good storability of onion bulbs.
\end{abstract}

Keywords: Dessication, DLS, neck, rotting, relative humidity, sprouting, temperature

\section{INTRODUCTION}

Irrigated farming by small scale farmers is being increasing in Fogera, Dera and Libokemkem areas of northwestern Ethiopia. These areas have rich water potential and cultivable land for irrigated horticulture. In addition to small rivers and immense ground water potential, big rivers such as Rib and Gumara are also available to construct big dams for irrigated farming. The expansion of irrigation is further motivating growers in those Woreda and their surroundings to produce vegetables throughout the year (twice and three times in a year). Onion and tomato are the major vegetable crops widely cultivated during the dry season using irrigation in Fogera, Dera and Libokemkem districts. Parallel to the expansion in the production system, farmers are however facing several challenges of production and marketing. These include build up of disease and insect pests leading to low productivity and poor quality produce. Despite the importance of vegetables in the daily diet of the people and ever increasing demand throughout the year, the other challenge of the sector is seasonality of production and concomitant abundance and scarcity in supply of vegetable produces. Fluctuations in the supply in the market is therefore leading to market glut during a season forcing growers to sell with very low price, while price climbs up at another time when there is shortage of supply.

Onion bulbs produced in the dry season are harvested at a similar time and the market is over flooded resulting in lower price. Because of lack of awareness on bulb curing techniques, bulbs cannot be stored for few days or weeks without significant bulb loss due to rotting and sprouting. Curing is a process of drying of the neck tissue and of the outer leaves to form dry scales. Appropriate harvesting 
time and curing techniques help to improve shelf life without significant bulb deterioration thereby helping to stabilize market price. Furthermore, bulbs for seed purpose need to be stored long till the next growing season. This requires selected healthy bulbs cured with appropriate method. Time and techniques of harvesting, and curing methods are therefore crucial.

Bulbs are living plant parts liable to high storage losses because of their high water content. Once harvested their internal food and water reserves decline over time. As a result, bulbs are subject to sprouting, rotting and shrinkage losses during storage. Brewster (1997) reported that cultivars differ widely in their duration of dormancy, though the storage environment is also important. Bulbs require a special storage condition to minimize losses and keep them firm and fresh for a reasonable period of time without significant deterioration. Such facilities are, however, costly and unavailable at research centers let alone at farmer's level in Ethiopia. Onion bulbs harvested from farms pass through several traders or middlemen before they reach the consumers. Postharvest losses are incurred at each channel in the supply chain that the produce passes through. Post-harvest handling practices that lowers the rate at which food and water reserves are used up reduces the rate of deterioration thereby improving storability of bulbs.

The time of sprouting, rotting and loss in weight of stored onion bulbs varies greatly with cultivar and pre- and post - harvest management practices. Moreover, pre-harvest management practices such as rate of fertilization, irrigation intensity and the use of sprout suppressant (maleic hydrazide) affect the storage performance of onion. Harvesting time, careful handling during harvesting and post harvest management practices such as method of drying (curing), topping techniques and degree of contamination of bulbs by pathogenic organisms also contribute towards the success of onion storage. According to Noureddine (2003), good and long-term storage of onion bulbs of improved quality depends on cultural conditions, the stage of maturity of the bulbs at harvesting, the techniques of harvesting and also environmental and biological conditions. Maintaining keeping quality of bulbs require appropriate handling practices and communication throughout the supply chain as each step is influenced by the previous; it is a chain of interdependent activities.

In general, appropriate harvesting time and post-harvest curing techniques help to improve the shelf life (storage quality) of onion, which in turn increase the return from onion production and stabilize the market situation. Proper postharvest handling can complement improved production technology in its goal to meet the demand for this perishable commodity.

This study was therefore initiated with the aim of developing appropriate harvesting time, curing (drying) and topping (foliage removal) techniques thereby minimizing post- harvest losses and improving storage performance of onion bulbs. While the ultimate goal of this study is to improve storability of onion, specific objectives include determining appropriate harvesting time and curing techniques (duration and techniques of foliage drying) to improve storability of onion bulbs.

\section{MATERIAL AND METHODS}

\subsection{Seedling Raising and Main Field Management}

Seeds of onion variety Bombay red were sown eight weeks ahead of the transplanting date in the main field. Seedlings were raised in the nursery bed of the research center on $5 \mathrm{~m} \times 1 \mathrm{~m}$ thoroughly prepared three adjacent beds, $5 \mathrm{~cm}$ raised from the surface. Seeds were drilled on rows with ten $\mathrm{cm}$ inter-row spacing and it was covered lightly with fine soil and mulched with eucalyptus leaves until emergence. Weeding was accomplished as deemed necessary. Water was regularly applied to seedling beds (seeds till emergence and thereafter seedlings) using watering can.

Experimental field was thoroughly plowed and leveled, and ridges were then prepared on sides of which transplanting was done. This harvesting time trial was done on farmers' fields at Wortea zuria (2016/17) and Quar Michael (2017/18) kebeles of Fogera district of South Gondar zone in Ethiopia. These kebeles are located in the vicinity of Fogera Agricultural Research Center. The Center is found in Woreta town of Fogera district of South Gondar Administrative zone in Amhara Region, Ethiopia.

Spacing used was $40 \mathrm{~cm} * 20 \mathrm{~cm} * 7 \mathrm{~cm}$ between furrows, rows and plants, respectively. Inorganic fertilizers in the form of Urea (46:0:0) (100kg/ha) and Nitrate phosphate sulfur (NPS) (19:38:7) $(242 \mathrm{~kg} / \mathrm{ha})$ were applied. NPS was applied at transplanting while urea is applied in two splits, the first at seedling establishment (1-2 weeks after transplanting) and the second one and half months after 
transplanting. Weeding \& cultivation were performed as deemed essential during the growing season following standard field management practices. These harvesting time trials in off seasons of 2016/17 and 2017/18 were irrigated trials where furrow irrigation was the only practice employed once in a week starting at transplanting until two to three weeks before harvest. Harvesting was made at five different stages of maturity (at full physiological maturity, at 25, 50, 75 and 100\% foliage fall over).

\subsection{Treatment and Experimental Design}

The experiment had three factors namely, onion harvesting time with five levels; drying technique with two levels (drying onion bulbs with the foliage by piling up together and by lightly spreading on the shelves of a diffused light store (DLS). The third factor had three levels of drying period, i.e., zero drying (removing or cutting foliage without leaf drying retaining only $1 \mathrm{~cm}$ neck with the bulb), one week drying (cutting leaves after drying for a week) and two weeks drying ( removing foliage at $1 \mathrm{~cm}$ length after drying for two weeks on shelves of a DLS). Drying was finally accomplished for zero days, seven days (one week) or two weeks by pilling up or spreading bulbs with leaves on shelves of a DLS.

Harvested onion bulbs with foliages were allowed to dry and cure on wire-mesh and wooden made shelves in a DLS. Two techniques of drying (piling together and spreading on shelves) with three drying periods before leaf cutting were evaluated. These are zero drying (leaf removal without drying), one week and two weeks drying. Cutting leaves or top removal was made with a knife retaining only one $\mathrm{cm}$ long neck with the bulb.

One-hundred uniform sized bulbs with good appearance (free from injury and physical damage) were selected from each combination of treatments, weighed and stored in cloth bags at ambient temperature and relative humidity on shelves of a light diffused storage with wire-mesh wall and shelves. The Design employed was completely randomized design with three replications. At a week interval, number and weight of consumable bulbs were recorded for each treatment. Rotten, sprouted and other non-consumable bulbs due to shrinkage or otherwise were counted and removed to avoid contaminating the rest healthy bulbs. Data was subjected to analysis of variance using SAS software version 9.2 and least significance difference (LSD) was used to compare treatment means when there was statistically significant difference $(\mathrm{P}<0.05)$.

\section{RESULT AND DISCUSSION}

Eight weeks old seedlings of variety Bombay red were transplanted in the field for harvesting time study. Drying and curing techniques were applied on those bulbs harvested at different maturity stages. Onion seedling transplanting was made in the of December 2016 and 2017 while the first harvest at full physiological maturity was made in mid April in 2017 and 2018. Storage Performance evaluations of bulbs were then made on wire-meshed and wooden shelves of a DLS from April to July in 2017 and 2018. Mean result on onion bulb storability revealed that almost all interactions with the exception of harvesting stage and year were insignificant $(\mathrm{P}<0.05)$. The effect of drying techniques (method) on shelf life of onion bulbs was also found insignificant. On the other hand, significant difference on onion bulb storability was recorded from different stages of harvesting (Tables 1 and 2). Siddiqui and Dhua (2010) reported that maturity always has a considerable influence on the quality of fresh produce as well as the storage potential and occurrence of many storage disorders. Drying periods also significantly affected shelf life of bulbs on weight basis for storage periods of four and eight weeks while it is insignificant for storage period of twelve weeks (Table 2). On basis of bulb number, drying period is insignificant for four weeks of storage life, but significant for eight and twelve weeks of bulb storage (Table 1).

Table1: Interaction of factors on percent marketable bulb number over storage periods

\begin{tabular}{|l|l|l|l|}
\hline \multicolumn{1}{|c|}{ Treatment } & \multicolumn{3}{c|}{ Storage period in weeks } \\
\hline Harvest time(HT) & \multicolumn{1}{|c|}{ Four } & Tight & \multicolumn{1}{c|}{ Twelve } \\
\hline Drying weeks (DW) & S & S & S \\
\hline Drying method (DM) & NS & S & S \\
\hline Year (YR) & NS & NS & NS \\
\hline HT*DW & S & NS & S \\
\hline HT*DM & S & NS & S \\
\hline HT*YR & NS & NS & NS \\
\hline
\end{tabular}


The Influence of Harvesting Time and Curing Techniques on Storability of Onion Bulbs

\begin{tabular}{|c|c|c|c|}
\hline$\overline{\mathrm{DW}} * \mathrm{DM}$ & NS & NS & NS \\
\hline $\mathrm{DW} * \mathrm{YR}$ & $\mathrm{S}$ & NS & NS \\
\hline DM*YR & NS & NS & NS \\
\hline HT*DW*DM & NS & NS & NS \\
\hline HT*DW*YR & NS & NS & NS \\
\hline HT*DM*YR & NS & NS & NS \\
\hline DW*DM*YR & NS & NS & NS \\
\hline $\mathrm{HT}^{*} \mathrm{DW}^{*} \mathrm{DM}^{*} \mathrm{YR}$ & NS & NS & NS \\
\hline
\end{tabular}

$S=$ significant and $N S=$ non significant

Table2: Interaction of factors on percent marketable bulb weight over storage periods

\begin{tabular}{|l|l|l|l|}
\hline \multicolumn{1}{|c|}{ Treatment } & \multicolumn{3}{c|}{ Storage period in weeks } \\
\hline Harvest time(HT) & \multicolumn{2}{c|}{ Four } & \multicolumn{2}{c|}{ Tight } & Twelve \\
\hline Drying weeks (DW) & S & S & S \\
\hline Drying method (DM) & S & S & NS \\
\hline Year (YR) & NS & NS & NS \\
\hline HT*DW & S & NS & S \\
\hline HT*DM & NS & NS & NS \\
\hline HT*YR & NS & NS & NS \\
\hline DW*DM & NS & S & S \\
\hline DW YR & NS & NS & NS \\
\hline DM*YR & NS & NS & NS \\
\hline HT*DW*DM & NS & NS & NS \\
\hline HT*DW*YR & NS & NS & NS \\
\hline HT*DM*YR & S & NS & NS \\
\hline DW*DM*YR & NS & NS & NS \\
\hline HT*DW*DM*YR & NS & NS & NS \\
\hline
\end{tabular}

After four weeks of storage period, harvesting at 100 percent foliage fall over $(90.74 \%)$ and at full physiological maturity $(89.69 \%)$ had the highest marketable bulb on weight basis. However, after eight $(84.19 \%)$ and twelve $(60.63 \%)$ weeks of bulb storage period, the highest saleable bulb was obtained from harvesting stage at 25 percent foliage fall over (Table 3). Agblor and Waterer (2001) indicated that onions are ready for harvest when the necks are reasonably dry and the tops have fallen over.

Table3: Percent marketable bulb weight over storage periods

\begin{tabular}{|l|l|l|l|}
\hline \multicolumn{1}{|c|}{ Treatment } & \multicolumn{3}{c|}{ Storage period in weeks } \\
\hline Harvesting time & Four & Eight & Twelve \\
\hline Physiological maturity & $89.69^{\mathrm{ab}}$ & $81.62^{\mathrm{a}}$ & $59.11^{\mathrm{a}}$ \\
\hline 25\% foliage fall over & $86.95^{\mathrm{bc}}$ & $84.19^{\mathrm{a}}$ & $60.63^{\mathrm{a}}$ \\
\hline 50\% foliage fall over & $84.47^{\mathrm{c}}$ & $79.52^{\mathrm{ab}}$ & $42.17^{\mathrm{b}}$ \\
\hline 75\% foliage fall over & $87.17^{\mathrm{bc}}$ & $74.14^{\mathrm{bc}}$ & $27.90^{\mathrm{c}}$ \\
\hline 100\% foliage fall over & $90.74^{\mathrm{a}}$ & $71.57^{\mathrm{c}}$ & $31.71^{\mathrm{c}}$ \\
\hline LSD & 3.27 & 5.74 & 4.29 \\
\hline CV\% & 7.99 & 15.72 & 20.76 \\
\hline Drying weeks & & & \\
\hline Zero & $82.85^{\mathrm{b}}$ & $73.78^{\mathrm{b}}$ & 43.30 \\
\hline One week & $89.10^{\mathrm{a}}$ & $78.02^{\mathrm{b}}$ & 44.81 \\
\hline Two seeks & $91.46^{\mathrm{a}}$ & $82.83^{\mathrm{a}}$ & 44.81 \\
\hline LSD & 2.54 & 4.44 & 3.33 \\
\hline Drying Method & & & \\
\hline Spreading & 86.94 & 78.36 & 44.83 \\
\hline Pilling up & 88.66 & 78.06 & 43.78 \\
\hline LSD & 2.07 & 3.63 & 2.72 \\
\hline
\end{tabular}

After twelve weeks of bulb storage, significantly low marketable bulb weight was recorded from harvesting periods at 75 and $100 \%$ foliage fall over. Similarly, the highest marketable bulb over storage periods of four $(91.46 \%)$, eight $(82.83 \%)$ and twelve $(44.81 \%)$ weeks was recorded from two weeks of drying (curing) on shelves of diffused light store (Table 3). This is inconformity with the report from Ahmad and Siddiqui, (2016) that onion and garlic require at least one week curing process 
to dry out outer scaly leaves and tightening of neck portion. Since water loss by transpiration is a major cause of product deterioration during post harvest activities (Vigneault, et al, 2003), drying is necessary to initially remove surface moisture and subsequent drying to cure the outer skins and to seal the necks so that shelf life of bulbs would be improved. However, insignificant difference between the two drying methods (drying by spreading and pilling together up) before foliage removal was observed on the effect of saleable onion bulbs over storage periods.

On the basis of bulb number, harvesting time at physiological maturity followed by at 25 percent foliage fall over gave consistently high marketable bulb number over storage periods of four, eight and twelve weeks (Table 4). Percentage marketable bulbs, on number basis, after storage periods of four weeks ranged from $92.71 \%$ (for harvesting stage at $75 \%$ foliage fall over) to $99.12 \%$ (for harvesting stage at physiological maturity). The lowest percentage saleable bulb number was recorded from harvesting stage at $75 \%$ foliage fall over (32.73\%) (Table4). Statistically insignificant difference $(\mathrm{P}<0.05)$ was observed in percentage marketable bulb number among drying weeks and drying methods.

Table4: Percent marketable bulb number over storage periods

\begin{tabular}{|c|c|c|c|}
\hline Treatment & \multicolumn{3}{|c|}{ Storage period in weeks } \\
\hline Harvesting time & Four & Eight & Twelve $^{\mathrm{a}}$ \\
\hline Physiological maturity & $99.12^{\mathrm{a}}$ & $94.98^{\mathrm{a}}$ & $71.28^{\mathrm{a}}$ \\
\hline $25 \%$ foliage fall over & $97.12^{\mathrm{a}}$ & $93.51^{\mathrm{a}}$ & $47.74^{\mathrm{b}}$ \\
\hline $50 \%$ foliage fall over & $94.94^{\mathrm{c}}$ & $88.04 \mathrm{~b}$ & $32.73^{\mathrm{c}}$ \\
\hline $75 \%$ foliage fall over & $92.71^{\mathrm{d}}$ & $77.54^{\mathrm{c}}$ & $37.73^{\mathrm{c}}$ \\
\hline $100 \%$ foliage fall over & $96.77^{\mathrm{b}}$ & $77.48^{\mathrm{c}}$ & 16.86 \\
\hline LSD & 1.57 & 3.09 & 55.89 \\
\hline CV\% & 3.49 & 7.67 & 51.07 \\
\hline Drying weeks & & & 50.21 \\
\hline Zero & 96.33 & 88.22 & 3.19 \\
\hline One week & 95.68 & 84.38 & 52.71 \\
\hline Two seeks & 96.38 & 2.39 & 52.07 \\
\hline LSD & 1.21 & & 2.61 \\
\hline Drying Method & 96.21 & 86.41 & \\
\hline Pilling up & 96.06 & 1.95 & \\
\hline LSD & 0.99 & & \\
\hline
\end{tabular}

Regardless of the year-round constant demand for fresh bulbs, onions are produced in large quantities during dry season using irrigation. High storage losses usually compel producers to sell their produce immediately after harvest, the market is over flooded with bulbs and the price is very low at harvest time while the supply is low and the price is high at other times. According to Ahmad and Siddiqui (2016), quality deterioration starts as soon as it is harvested and continued till consumed or finally spoiled if not consumed or preserved. Applying good pre-harvest management and appropriate post harvest practices help producers and other actors involved in the value chain to benefit from improved bulb shelf life to fetch good market price. Moreover, it enables growers to keep their own bulbs for planting material from season to season for onion seed production. This would contribute towards reducing cost of onion seed production. To date, farmers in Ethiopia in general and in south Gondar zone in particular are unable to keep planting materials from their own harvest for the next planting season or year. As a result they buy planting materials during planting time, which are expensive. Wiles and Midmove (1994) reported that disease incidence (primarily Alternaria porri) and short storage life of existing cultivars are the main constraints to production system in Papua New Guinea. It is also reported that the formation of whole outer skins and a dry neck reduces moisture loss from the bulbs during storage and reduces the risk of fungal and bacterial infection. Siddiqui et al. (2015) noted that quality of fresh produce is governed by many factors. The combined effect of all decides the rate of deterioration and spoilage (Barman et al. 2015 and Nayyer et al. 2015).

\section{CONCLUSION}

This trial on onion storage was conducted starting April and May when the temperature was high in Fogera Center reaching up to $30^{\circ} \mathrm{C}$. It was followed by June and July when rainy season started and relative humidity was high. This is reflected in Table 3 that overall percentage loss in bulb weight 
was higher than overall percentage loss in bulb number (Table 4). Consumable bulb loss in June and July is mainly due to sprouting and rotting. This is attributable to high relative humidity in the rainy months favoring sprouting and pathogen development for bulb rotting. According to Tayler (1997), the higher the moisture content and the warmer the temperature of storage the more rapidly deterioration occurs.

Considering the interference of rainfall starting the second harvesting stage and other scientific justifications, harvesting at 25 percent foliage fall over is advised to solicit good price until eight weeks of storage period. Bulb storage for seed production is however possible up to three or four months storage life. In addition to cultivar differences, time of sprouting, rotting and loss in weight of stored onion bulbs vary greatly with harvesting stage and post- harvest management practices. Before foliage removal retaining one $\mathrm{cm}$ long neck with the bulb, drying and curing harvested onion bulbs with foliages for two weeks on wire-meshed and wooden shelves in a DLS at ambient temperature and relative humidity (or in a partially shaded condition) was found appropriate for good storability of onion bulbs.

\section{ACKNOWLEDGEMENT}

The author would like to thank Mr. Mulat Getaneh, Maru Adugna and Desalegn Sisay who did their best in managing the field bulb multiplication activities and data collection in the store. The former had also helped much in feeding the data into computer.

\section{REFERENCES}

[1] Agblor, S and D Waterer (2001). Onions post harvest handling and storage, Department of Plant Sciences, University of Saskatchewan

[2] Ahmad, MS and MW Siddiqui (2016). Factors Affecting Postharvest Quality of Fresh Fruits, Springer International Publishing, Switzerland.

[3] Barman, K, MS Ahmad \& MW Siddiqui (2015). Factors affecting the quality of fruits and vegetables: Recent understandings. In MW Siddiqui (Ed.), Postharvest biology and technology of horticultural crops: Principles and practices for quality maintenance (pp. 1-50). Waretown, NJ: Apple Academic Press.

[4] Siddiqui, MW \& RS Dhua (2010). Eating artificially ripened fruits is harmful. Current Science, 99(12), 1664-1668.

[5] Siddiqui, MW, VB Patel \& MS Ahmad (2015). Effect of climate change on postharvest quality of fruits. In M. L. Choudhary, V. B. Patel, M. W. Siddiqui, \& S. S. Mahdi (Eds.), Climate dynamics in horticultural science: Principles and applications (Vol. 1, pp. 313-326).Waretown, NJ: Apple Academic Press.

[6] Nayyer, MA, MW Siddiqui \& K Barman (2015). Quality of fruits in the changing climate. In M. L. Choudhary, V. B. Patel, M. W. Siddiqui, \& R. B. Verma (Eds.), Climate dynamics in horticultural science: Impact, adaptation, and mitigation (Vol. 2, pp. 269-278). Waretown, NJ: Apple Academic Press.

[7] Noureddine, B (2003). Postharvest technology of onions. In: Crop management and postharvest handling of horticultural crops. Vol. II - Vegetabkes and fruits (eds. Dris, R, R. Niskanen \& S. M Jain), Oxford \& IBH, New Delhi.

[8] Tayler, AG (1997). Seed storage, germination and quality. In: Wien, HC (Ed.). The physiology of vegetable crops. CABI publishing.

[9] Vigneault, C, GSV Raghavan, NR Markarian, JR DeE11, Y Gariepy \& B Goyette (2003). Techniques of modified and controlled atmosphere storage for fresh fruits and vegetables. In: Crop management and postharvest handling of horticultural crops. Vol. II - Vegetabkes and fruits (eds. Dris, R, R. Niskanen \& S. M Jain), Oxford \& IBH, New Delhi.

[10] Wiles, G and DJ Midmove (1994). Onion production in Papua New Guinea. International Symposium on Alliums for the Tropics, Bangkok, Thailand, 15-19 Feb. 1993. ActaHoticulturae 1994, No. 358, 123-126.

Citation: Dessie Getahun, (2019). "The Influence of Harvesting Time and Curing Techniques on Storability of Onion Bulbs" International Journal of Research Studies in Agricultural Sciences (IJRSAS), 5(1), pp.14-19, http://dx.doi.org/10.20431/2454-6224.0501003

Copyright: () 2019 Authors. This is an open-access article distributed under the terms of the Creative Commons Attribution License, which permits unrestricted use, distribution, and reproduction in any medium, provided the original author and source are credited. 